\title{
ПРОПАНТ ХӨӨСТ КАМЕРТ БУРТГЭГДСЭН ХАРИМХАЙ БУС ХАРИЛЦАН ҮЙЛЧЛЭЛЭЭР ҮУССЭН ЭЕРЭГ ЦЭНЭГТ БӨӨМИЙГ ЯЛГАН ТАНИХ НЭГЭН БОЛОМЖ
}

\author{
P.Тогоо ${ }^{1,2}$, T.Tулгаа $^{1}$, A.Төрсүх ${ }^{1}$ \\ О.В.Рогачевскийㄹ, М.Совд ${ }^{1,2}$, Ж.Шинэбаяр ${ }^{3}$ \\ ${ }^{1}$ Физик технологийн хурээлэн, Шинжлэх ухааны Академи, Монгол улс \\ ${ }^{2}$ Их энергийн физикийн лаборатори, Цөмийн шинжсилгээний нэгдсэн институт, Дубна, ОХУ \\ ${ }^{3}$ Монгол улсын Боловсрольнн Их сургууль \\ Цахим иуудан: togoomas@gmail.com
}

Редакиид ирҮҮлсэн: 2016.03.03

Товч агуулга: Релятив энергийн мужид ажилладаг молекуляр квант динамикийн загвар дээр тулгуурлан, их энергитэй эерэг бөөмийг ялган таних бэрхшээлийг гиперболлог буюу Лобачевскийн огторгуй дахь бүтэн хурдаи хэмээх хэмжигдэхүун ашиглан, протонуудын $25.3 \%$ нь $\pi^{+}$- мезонууд байсныг арилгаж чадлаа. Ингээд $\pi^{+}$- мезоны шинж чанарыг судлах боломжтой болов.

ТүлхүҮр үг: Лобачевский огторгуй, энерги, импульсийн хөндлөн ба дагуу байгууллагчид, хурдаи, UrQMD 1.3 загвар, кумулятив хувьсагч, дөхүҮлэлт

\section{ОРШИЛ}

Бүл процессыг судлах үед аливаа асуудлыг шийдвэрлэхэд тухайн хөдөлгөөний дагуу ба хөндлөн чиглэлийг зэрэг тооцсон хэмжигдэхүүнээр судлаж үзэх нь олон давуу талтай. Жишээлбэл, Лобачевскийн геометр [1,2] буюу хурдцын огторгуйд хэрэглэгдэх “бүтэн хурдац” гэж нэрлэдэг хэмжигдэхүүн нь дээр дурдсан хоёр чиглэлийг нэгэн зэрэг тооцсон.

Хурдцын огторгуй дахь бөөмийн тархалт буюу түгэлтүүдийн геометр үзүүлэлтэд хөдөлгөөний дагуу чиглэлд буулгасан дагуу хурдцыг $y=\frac{1}{2} \log \frac{E+p_{\|}}{E-p_{\|}}$харин хөндлөн массыг $m_{T}=\sqrt{m^{2}+p_{T}^{2}}$ гэсэн илэрхийллээр тодорхойлдог. Энд $E, m, p_{\|}$ба $p_{T}$ нь тухайн бөөмийн энерги, масс, импульсийн дагуу байгуулагч ба хөндлөн байгуулагчийг тэмдэглэсэн. Цаашид хөндлөн хурдац $\tau$ нь $\operatorname{ch}(\tau)=\frac{m_{T}}{m}$ гэж илэрхийлэгдэнэ.

Бүтэн хурдац $\rho$ бол Лобачевскийн огторгуйд Пифагорын теоремыг ашиглан дагуу болон хөндлөн хурдцуудаар тодорхойлдог: $\operatorname{ch}(\tau)=\operatorname{ch}(y) \cdot \operatorname{ch}(\tau)$. Энэ огторгуйд энгийн гурвалжнаар судалж буй эгэл бөөмийг бай болон сум объекттой харьцангуйгаар дүрслэн, олон бөөмийн бүлээр үүсэх (бүл) процесст энергийн шилжилтийн муж байгааг туршилтаар судласан билээ [2]. Энд илэрсэн фазын шилжилт нь камер дотор бүртгэгддсэн эерэг цэнэгт бөөмийн буруу ангилсантай -5 - 
холбоотой бөгөөд бүтэн хурдац нь бөөмийн массыг буруу олгосныг дагуу хурдацтай харьцуулан үзэхэд ямар нэгэн тодорхой байрлалд илүү мэдэрдэг хэмжигдэхүүн учраас бид энэ хэмжигдэхүүнийг хэрэглэж байна.

Тухайлбал, бүл процессыг судалдаг хөөст камерын аргад 1 ГэВ/с-ээс их импульстэй эерэг бөөмийг ялган танихад бэрхшээлтэй. $4.2 \div 10$ А ГэВ энергийн мужид хуримтлагдсан туршилтын материалд энэ эерэг бөөмийг бүгдийг “протон” гэж тооцдог бол 40 ГэВ-ийн сөрөг пионы пропан дотор мөргөлдсөн мөргөлдөөний хувьд тэдгээрийг эерэг пион буюу “ $\pi^{+}$мезон” гэж үздэг.

Энэ ажилдаа Лобачевскийн огторгуйг ашиглан бид эхлээд 10 ГэВ-ийн $\mathrm{pC}$ үйлчлэлийн хувьд дээрх протон руу алдагдсан $\pi^{+}$-мезонуудыг протоноос салгах шинэ аргачлалыг боловсруулснаа нийтэлж байна.

\section{ЭЕРЭГ ПИОНЫ АЛДАГДЛЫГ ТОДОРХОЙЛСОН НЬ}

Зураг 1а-д 10 ГэВ-ийн харимхай бус гэж ангилсан бөөмсийн олонлог $(\mathrm{N})$, pC-үйлчлэлээр үүссэн цэнэгт хоёрдогч дагуу хурдац $\left(\mathrm{y}_{\mathrm{lab}}\right)$ ба хөндлөн импульс бөөмс болох “ $\pi$-ба $\pi^{+}$-мезон болон протон” $\quad\left(\mathrm{P}_{\mathrm{T}}\right)$-ийн $\quad$ түгэлтүүдийг, $\quad$ харин
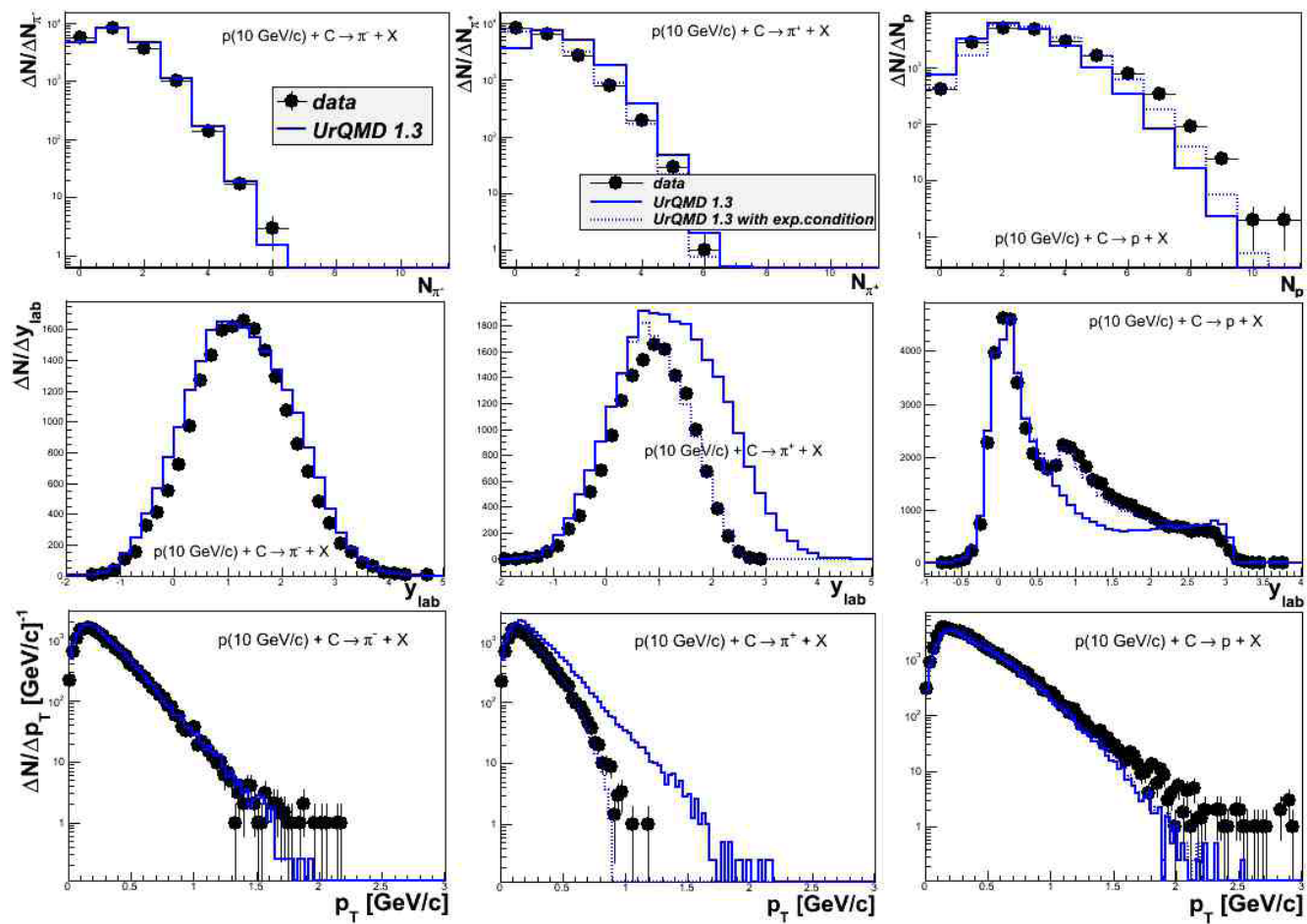

Зураг 1a. 10 ГэВ-ийн $p C$-үйлчлэлээр үүссэн “иэнэгт хоёрдогч бөөмс”-ийн олонлог, дагуу хурдаи болон хөндлөн импульсийн тархалтууд. Энд хар иэгээр туршилтын ба гистограммууд нь UrQMD

1.3 загварын дүн, харин тасархай гистограммууд UrQMD 1.3 загварт туршлагын нөхиөлийг тооисон үр дүнгүҮд. Зүүн гар тальн босоо 3 зургууд нь $\pi$-мезоны, дундах босоо 3 зургууд $\pi^{+}$-мезоны хувьд бол баруун гар талын босоо 3 зургууд нь протон гэж ялгаж ангилсан бөөмст харгалзана. Тасархай шугамуудаар онольн загвар UrQMD-ын хувьд 0.9 ГэВ/с-ээс их импульстэй эерэг пионыг “протон” гэж өөрчлөлт хийн дахин бодсон протонуудын түгэлтүҮд. 
1б-д нь тэдгээрийн бүтэн хурдац $\left(\rho_{23}\right)$ ын тархалтуудыг харгалзуулан үзүүлэв. Энд Bevalac ба SIS-аaс эхлээд AGS, SPS төдийгүй RHIC хурдасгуурууд дээр гарган авч буй энергийн мужуудад хэрэглэж болдог (ультра) релятив молекуляр квант динамик хэмээх UrQMD 1.3 загвар [3]-ын дүнг хавсарган үзүүлсэн. Энд нь тухайн бөөмийг 3 , бай цөмийг 2 гэж тэмдэглэсэн.
Эхлээд бид UrQMD 1.3 загвар туршлагын материалд ямар нэгэн засвар өөрчлөлт хийгээгүй харалт-хэмжилтийн дараaх үр дүнг хэрхэн тайлбарлаж байгааг үзье. Зураг 1-ээс харахад UrQMD 1.3 загварчлал туршилтын өгөлтийг “удаан” гэж нэрлэдэг бага энергитэй буюу импульс $\left(\mathrm{p}_{\mathrm{lab}}<0.4\right.$ ГэВ/с)-тэй протоныг эс тооцвол сайн тайлбарлаж байна.
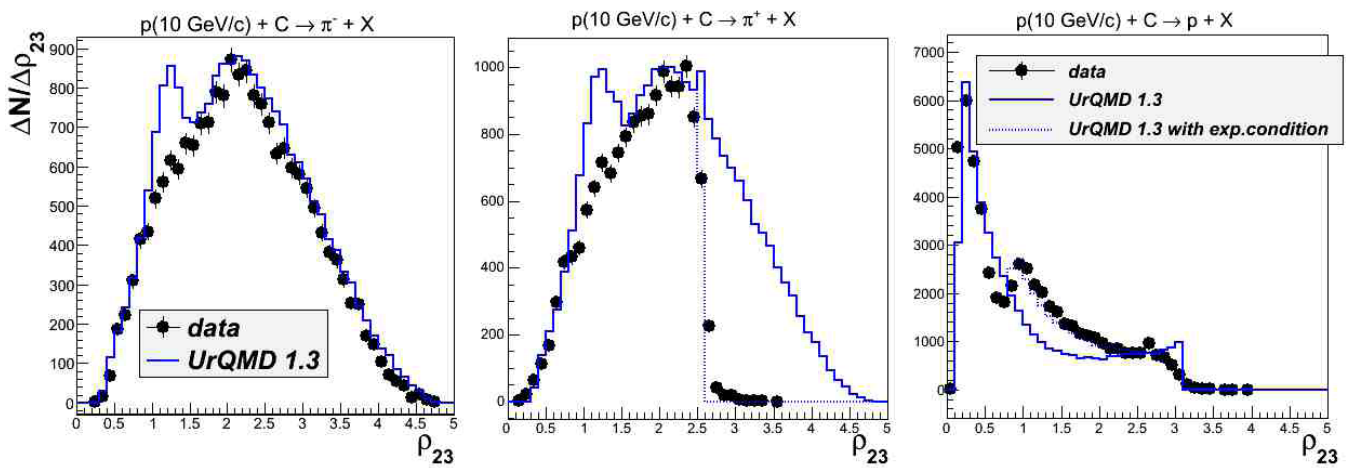

Зураг 1б. 10 ГэВ-ийн рС-үйлчлэлээр үүссэн “ $\pi$ - ба $\pi^{+}$мезон болон протон”- уудын бүтэн хурдаи $\left(\rho_{23}\right)$-ынн тархалтууд. Тэмдэглэлүүд Зураг 1а-тай адилхан.

Зураг 1б-ийн эхний 2 түгэлтүүдээс харахад, $\pi^{-}$- ба $\pi^{+}$-мезоны хувьд бүтэн хурдац $\rho_{23}$-ийн түгэлтүүдэд UrQMD 1.3 загвараар Үүссэн цэнэгт каонуудыг бид пион гэж дахин тооцоолсон ч $\rho_{23} \sim 1.2$ орчим нэмэлт пионы гаралтууд (буюу бөхүүд)-тай холбоогүй. Онолын энэ загварт 0.9 ГэВ/сээс их импульстэй $\pi^{+}$-мезоныг “протон” гэж үзээд, $\pi^{+}$-мезоны массыг протоны масс болгон хувиргаж, масс оруулан тодорхойлогддог физик хэмжигдэхүүнүүд болох энерги, дагуу ба бүтэн хурдцуудыг дахин бодоод, харгалзах түгэлтүүдийг байгуулан зурахад $y_{\text {lab }} \sim 1$ ба $\rho_{23} \sim 1$ үед нэмэлт бөх гарч байна. Протоны хувьд ажиглагдаж байгаа энэ бөх туршилтын түгэлтэд ч ажиглагдаж байдаг бөгөөд үүнийг арилгах “жин”-г олон жилийн өмнө оруулсан [4]. Энэ жин хэрхэн орсныг зураг 2-д харуулав. Энэ зургаас харахад $1<\rho_{23}<2.7$ мужид засвар бараг зөв орсон боловч $0.6<\rho_{23}<1$ интервалд огт оруулах ёсгүй жинг оруулсан байна. Үүнийг Зураг 2-ын дунд буюу $\pi^{+}$-мезоны тархалт нь $\pi^{-}$мезоныхоос эрс ялгаатайгаас тодорхой харж болно. Ингээд бид зураг 16 дэх баруун талд үзүүлсэн протоны хувьд түүний бүтэн хурдцын $0.8<\rho_{23}<2.9$ интервалд туршилт болон онолын хувьд байгаа илүүдлийг UrQMD 1.3 загвараар үүссэн “жинхэнэ” протоны түгэлттэй харьцуулан холбогдох “жин”-г шинээр оруулсан. Энэ жинг Зураг 3 дээр үзүүлсэн ба түүнийг 7-р эрэмбийн Лежандрын полиномоор дөхүүлэлт хийлээ. Энэ полиномын хэлбэрээр олдсон хамаарал шинэ жингийн утгыг шууд тодорхойлно. Зураг 3-аaс үзэхэд туршлагын шинээр жигнэсэн өгөгдлүүд онолын үр дүнтэй ойролцоо байна. Үүнээс гадна цэнэгт пионууд болон протонуудын хувьд шинэ жингээр жигнэсэн олонлог, дагуу хурдац ба хөндлөн импульсийн түгэлтийг шинээр байгуулан, Зураг 4-д үзүүллээ. 

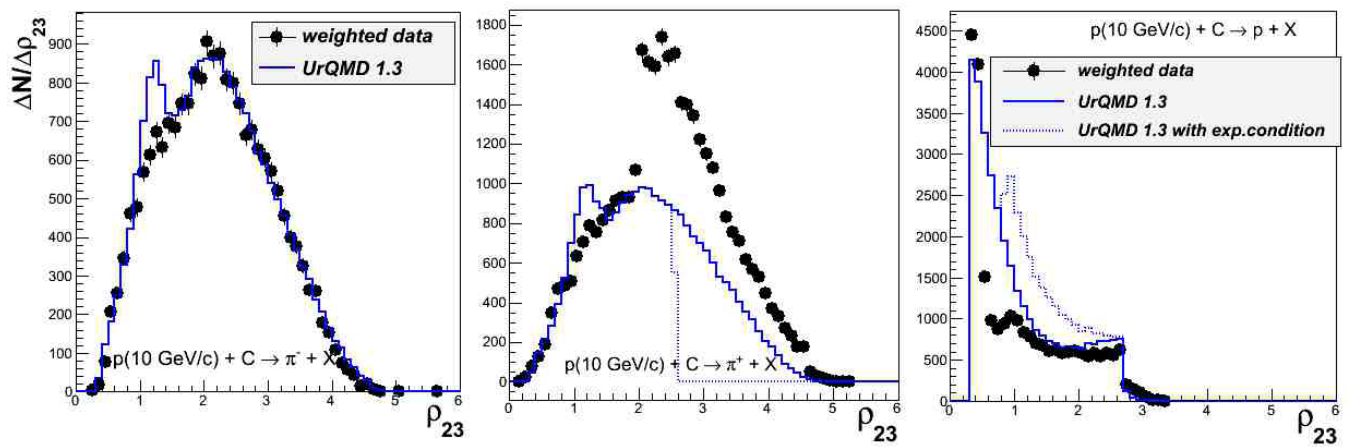

Зураг 2. 10 ГэВ-ийн рС-үйлчлэлээр Үүссэн “ $\pi$ - ба $\pi^{+}$-мезон болон протон”-уудын бүтэн хурдиын хувьд [3] ажилд оруулсан “жин” тооисон тархалтууд. Тэмдэглэлүүд Зураг 1-тай адилхан.

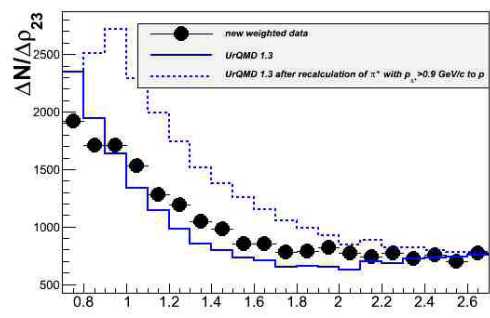

Зураг 3. Харимхай бус рС-үйлчлэлээр Үүссэн протоны бүтэн хурдиын түгэлт (Дээд талынх). Тэмдэглэлүүд Зураг 1-тай адилхан. Энд үзүҮлсэн хар иэгуҮд бол туршлагын протонь түгэлтийг “иинэ жин”-гээр жигнэсэн үр дүн. Доод тальн зурагт UrQMD загвараар ҮҮссэн “жинхэнэ” протонуудын түгэлт буюу гистограммыг 0.9 ГэВ/с-ээс их импульстэй $\pi^{+}$-мезоныг протон болгосон тасархай гистограммаар

ҮзҮүлсэн түгэлттэй харьиуулсан харьияааны бүтэн

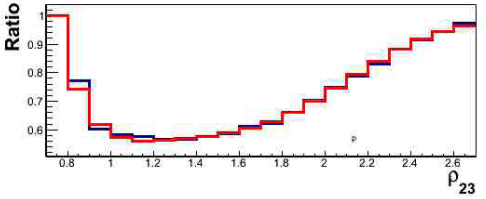
хурдиын хамаарал. Энд улаан гистограммаар 7-р эрэмбийн Лежандрын полиномоор дөхүүлэлт хийсэн хамаарал.

Ингээд бид $\pi^{+}$-мезоныг 5 ба протоныг 7 гэж тэмдэглэдэг уламжлалтайг харгалзан бүтэн хурдцын $0.8<\rho_{23}<2.9$ мужид харгалзах $\pi^{+}$-мезоныг протон болгосныг 75 гэсэн тэмдэглэлгээ оруулаад, туршилтын эх материалд байсан 7 гэснийг 75 болгосон. 75 имтэй протонуудыг бүх протонуудын тоотой харьцуулсан хувийг Хүснэгт 1-д үзүүлсэн. Энэ хүснэгтээс харахад онол ба туршилтын хувиуд ойролцоо байна. Туршилтын өгөлтүүдэд оруулсан шинэ жингээр тооцоолсон протонуудын тоог бүх протон гэж 75 имтэй протонуудын тоотой харьцуулж үзвэл 25.3\% (13807.3/54660.2)тай, харин туршилтын явцад сайн ангилалт хийгдсэн $\pi^{+}$-мезоны тоотой харьцуулахад $90 \%$ (13807.3/15295.9)-тай тэнцэж байна. Бид туршилтын материалд байх ёстой бүх $\pi+$-мезоны хувьд 44.4\% (13807.3/29103.7)ийг протон гэж ангилалт хийсэн байв. Одоо $\pi^{+}$-мезон нь $\pi^{-}$-мезонтой харьцангуйгаар $35.4 \%$-аар их байна. Энэ нь онолын үзүүлэлттэй ойролцоо.

ХУснэгт 1. Хувиар илэрхийлсэн жингүУдийн хэмжээ

\begin{tabular}{|c|c|c|}
\hline ҮзҮүлэлт & Хуучин жин [3] & Шинэ жин \\
\hline UrQMD 1.3 & - & $17.3 \%$ \\
\hline Туршилт & $34.2 \%$ & $25.3 \%$ \\
\hline
\end{tabular}




\section{0 ГэВ-ИЙН рС-ҮЙЛЧЛЭЛ БА URQМD ЗАГВАРЧЛАЛ.}

Бид туршлагын материалд байсан гол засварыг хийсэн тул харимхай бус протоннүүрстөрөгчийн харилцан үйлчлэлийн ерөнхий үзүүлэлтийг авч үзье. Хүснэгт 2-д судалж буй харилцан үйлчлэлд үүссэн хоёрдогч бөөмсийн дундаж олонлогийн туршилт ба онолын дүнг нийтлэв.

ХУснэгт 2. Хоёрдогч бөөмсийн дундаж олонлогууд

\begin{tabular}{|c|c|c|}
\hline Хоёрдогч бөөмсийн төрөл & Туршилт & UrQMD 1.3 \\
\hline$<n_{ \pm}>$ & $5.15 \pm 0.02$ & 5.04 \\
\hline$<n_{\pi-}>$ & $1.09 \pm 0.01$ & 1.15 \\
\hline$<n_{\pi^{+}}>$ & $1.42 \pm 0.01$ & 1.35 \\
\hline$<n_{\mathrm{p}}>$ & $2.63 \pm 0.01$ & 2.54 \\
\hline$<n_{\text {slow }} p>$ & $0.68 \pm 0.01$ & 0.57 \\
\hline$<n_{\pi 0}>$ & - & 1.23 \\
\hline$<n_{\mathrm{n}}>$ & - & 1.99 \\
\hline $\mathrm{N}_{\text {event }}$ & 18629 & \\
\hline
\end{tabular}

Хүснэгт 2.-оос харахад UrQMD 1.3 түгэлтүүдийг Зураг 4.-д нэмж үзүүлсэн загварын таамаглал туршлагын өгөлтүүдийг ба онолын загварчлал, туршлагын үр сайн тайлбарлаж байна. Олонлог болон дүнгүүдийг чанарын хувьд тайлбарлаж бусад физик хэмжигдэхүүнүүдийн байна.
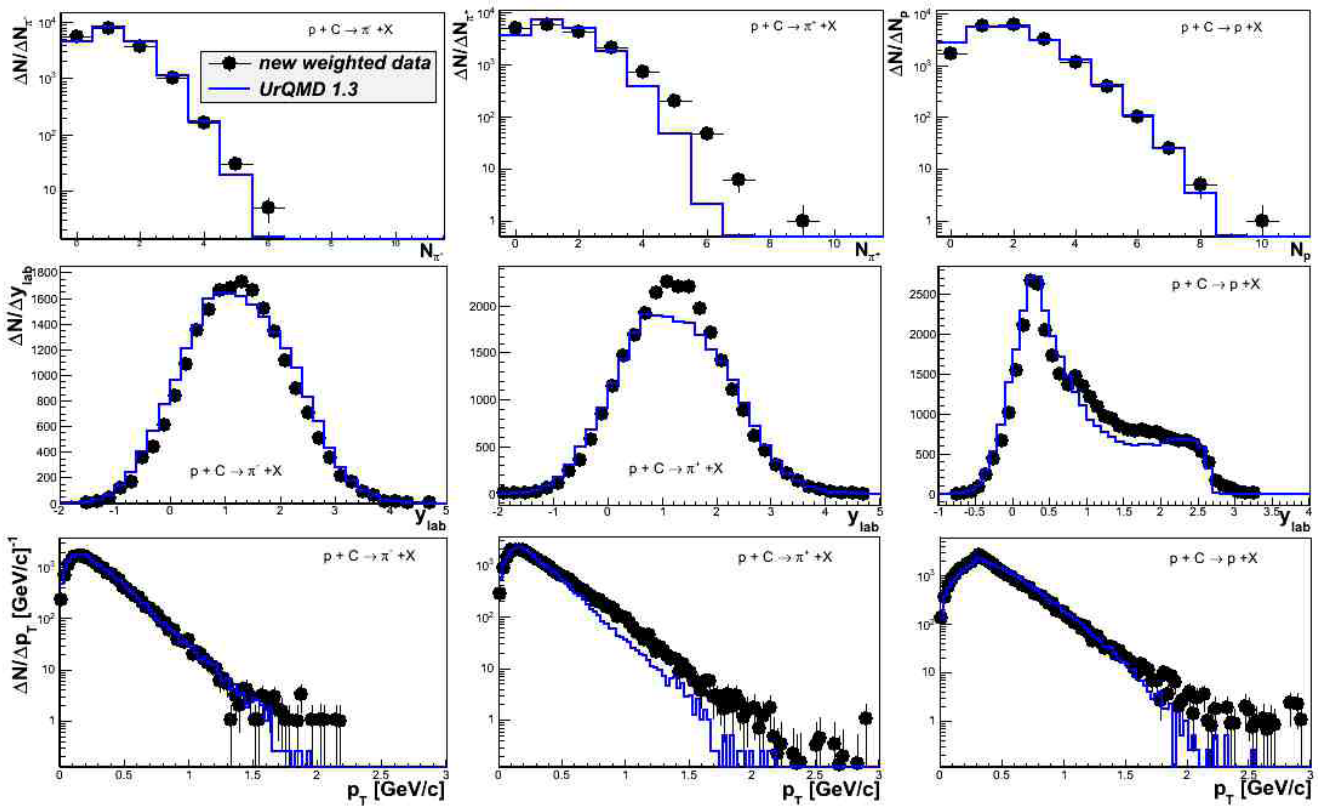

Зураг 4. Шинэ жингээр жигнэсний дараах 10 ГэВ-ийн $р$-үйлчлэлээр үүссэн “иээнэгт хоёрдогч бөөмс”-ийн олонлог, дагуу хурдац болон хөндлөн импульсийн тархалтууд. Тэмдэглэлүүд болон зургийн байрлал Зураг 1-тэй адилхан. 


\section{ЭЕРЭГ ПИОНЫ КУМУЛЯТИВ ПРОЦЕСС}

Бид зөвхөн сөрөг пион ба протоны кумулятив спектр, тэдгээртэй нэгэн зэрэг үүссэн цэнэгт ба саармаг бөөмсийн судалгааг инклюзив болон кластерын аргаар судалж байв $[5,6]$. Энэ удаа эерэг пионы хувьд судалгааг хийх боломжтой боллоо. Гэхдээ энэ эерэг пионы судалгааг протоны хувьд тодорхойлсон жинг нэгээс хассан хэлбэрээр тодорхойлж байсныг [4] дээр дурдсан ба Зураг 2-т үзүүлсэн.

Тухайн судалгааг хийхдээ Нар ба Орчлонгоос ирж буй гэрэлтэй холбоотойгоор “гэрлэн хувьсагч” $x_{\text {cum }}{ }^{-}$ ийг ашигласан. Энд $x_{\text {cum }}=\frac{E-p_{\|}}{m_{p}}$ гэж тодорхойлогддог. $E$-бөөмийн энерги, $p_{\|}$ импульсийн дагуу байгуулагч, харин $m_{p}$-протоны масс. Зураг 5-д сөрөг, эерэг цэнэгт пионууд болон протонуудын хувьд кумулятив хувьсагчийн түгэлтүүд (дээд талын 3 зургууд) ба судлаж буй гурван бөөмсийн хөндлөн импульсийн квадратын дундаж утгууд $\left(<p_{T}^{2}>\right)$ нь кумулятив хувьсагчаас хамаарах хамаарлыг үзүүлэв (доод талын 3 зургууд). Энэ зургаас харахад UrQMD 1.3 загварчлал туршлагын үр дүнг гайгүй тайлбарлаж байна. Гэхдээ эерэг пионы хөндлөн импульсийн квадратын дундаж утгууд нь $x_{\text {сит }}$-ээс хамаарах хамаарал онолын тооцооллоос нилээд зөрөөтэй байна. Үүний шалтгаан нь $0.8<$ $\rho_{23}<2.9$ интервалд байгаа бүх протонуудыг түүнд харгалзах жингээр авч үзсэнтэй холбоотой. Анх энэ кумулятив хувьсагчаас хөндлөн импульсийн квадратын дундаж утгуудын хамаарлыг ИТЭФ-ийн 1990-ээд оны эхэн үед тавигдсан бөөмийн сарнилын өнцөг нь тодорхой бэхэлсэн буюу $119^{\circ}$-ийн үед судалсан [7]. Зураг 5-аас протоны хувьд $x_{\text {cum }}>0.8$ үед ажиглагдаж буй шинж төлөв [7] ажилд хийсэн дүгнэлттэй зохицож байна.
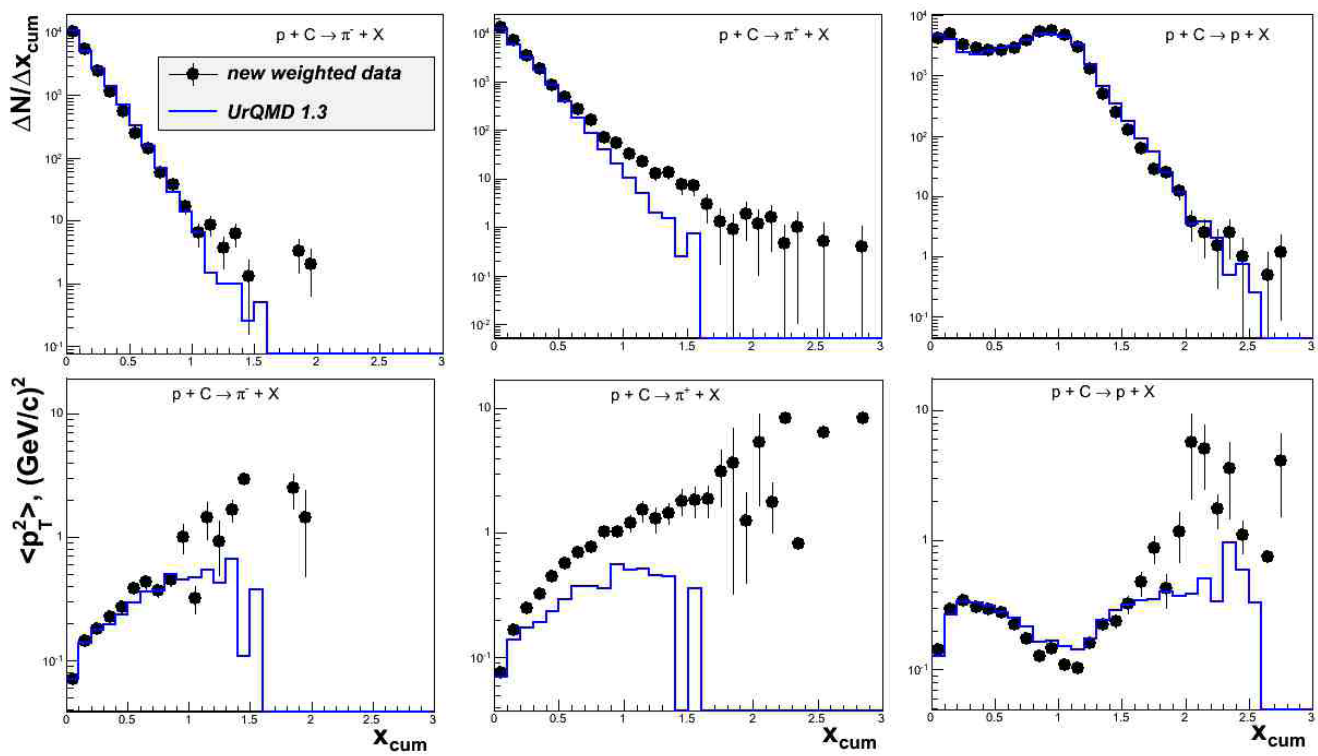

Зураг 5. Шинэ жинг тооисоны дараах 10 ГэВ-ийн рС-үйлчлэлээр ҮҮссэн “иэнэгт пионууд болон протонууд”-ийн кумулятив хувьсагч ба тэдгээрийн хөндлөн импульсийн квадратьлн дундаж утгууд кумулятив хувьсагчаас хамаарах хамаарлууд. Тэмдэглэлүүд Зураг 1-тэй адилхан. 


\section{ДУГНЭЛТ}

- Лобачевскийн буюу гипербол огторгуй дахь бүтэн хурдац хэмээх хэмжигдэхүүнийг ашиглан, 44\%-ийн $\pi^{+}$-мезонууд протон гэж андуурсныг шинээр жин оруулан тодорхойлж чадлаа. Зохих байрлалд оруулсан шинэ жингийн хувь хэмжээ урьд оруулсан жинтэй тоон утгаараа ойролцоо байна.

- UrQMD 1.3 загвар туршлагын дүнг сайн тайлбарлаж байна.

\section{ТАЛАРХАЛ}

Др. Б.Хүрэлбаатар болон проф. Ц.Баатар тасгийн эрдэм шинжилгээний ажилтан, нарт судалгааны явцад харилцан ярилцлага ба зөвлөгөө өгсөнд талархал илэрхийлье. Зохиогчдийн нэг Р.Тогоо ШУА-ийн Хэл зохиолын хүрээлэнгийн Төвд судлалын магистр Батжаргалын Лхагважавт бидний судалгааны ажлын товч утга санааг Монгол угсаатанд таниулахаар монгол бичгээр толилуулсанд гүнээ талархаж байна.

\section{Ашигласан бүтээлийн жагсаалт}

1. Н.А.Черников; Геометрия Лобачевского и релятивистская ядерная физика. - Дубна, 1997. - $16 \mathrm{c}$.

2. A.A.Baldin, E.G.Baldina, E.N.Kladnitskaya, O.V.Rogachevsky; Письма в ЭЧАЯ, 2004. T.1, №4 (121). C.7-16.

3. S.A. Bass et al.., Prog. Part. Nucl. Phys., 41 (1998) 225-370; nucl-th/9803035.

4. M. Bleicher et al.., J. Phys. G25 (1999) 1859-1896; hep-ph/9909407.

5. А.И.Бондаренко, Р.А.Бондаренко, Е.Н.Кладничкая, А.А.Кузнещов, Г.П.Тонеева и Б.С.Юлдашев; Препринт ОИЯИ, Р1-98-292, Дубна, 1998.

6. D.Armutlijskij et. al.; Preprint JINR, P1-85-939, Dubna 1985; Yad.Fiz. Vol.44, No.6, 1985, pp.1495-1501.; Preprint JINR, P1-86-459, Dubna, 1986; Yad.Fiz. Vol.45, No.6, 1987, pp.1676-1679. ; Preprint JINR, P1-87-97, Dubna, 1987; Yad.Fiz. Vol.47, No.3, 1988, pp.739-743.

7. D.K.Kopylova, V.B.Lyubimov, V.F.Nikitina, R.Togoo and D.Tuvdendorj; Comm. JINR, PI86-109, Dubna, 1986

8. N.Angelov, V.B.Lyubimov and R.Togoo; JINR. Rapid Comm. No.38-89, Dubna, 1989, p. 1125; Yad.Fiz. Vol.54, No.5 (11), 1991, pp.1316-1326; Comm. JINR No-5 [51]-91, Dubna, 1991. 14-22.

9. С.В.Бояринов и др. ИТЭФ-5, Москва, 1987; ЯФ, m.46, вып. 5(11), 1987, стр.1472-1481.

ЭнэхҮУ ажлыг ОХУ-ын Дубна хот дахь Цөмийн иинжилгээний нэгдсэн институт байгуулагдсаны 60 жилийн ойд зориулан ФТХ-ийн Физик процессын загварчлалын лабораторит хийж гүйщэтгэв. 


\title{
A POSSIBITY TO IDENTIFICATION FOR POSITIVE PARTICLES PRODUCED FROM THE INELASTIC INTERACTIONS DETECTED BY PROPANE BUBBLE CHAMBER
}

\author{
R.Togoo ${ }^{1}$, T.Tulgaa ${ }^{1}$, A.Tursukh', O.V.Rogachevsky², M.Sovd², J.Shinebayar ${ }^{3}$ \\ ${ }^{1}$ Institute of Physics and Technology, Mongolian Academy of Sciences, Ulaanbaatar, Mongolia \\ ${ }^{2}$ Joint Institute for Nuclear Research, Dubna, Russia \\ ${ }^{3}$ Mongolian National University of Education, Ulaanbaatar, Mongolia \\ E-mail: togoomas@gmail.com
}

Abstract: Based on the quantum molecular dynamics model which works for the relativistic energy range, we managed to identify positive particle with high energy using the total rapidity in hyperbolic or Lobachevsky space. $25.3 \%$ of all identified protons had removed to $\pi^{+}$mesons. Then we were able to study the feature of $\pi^{+}$mesons.
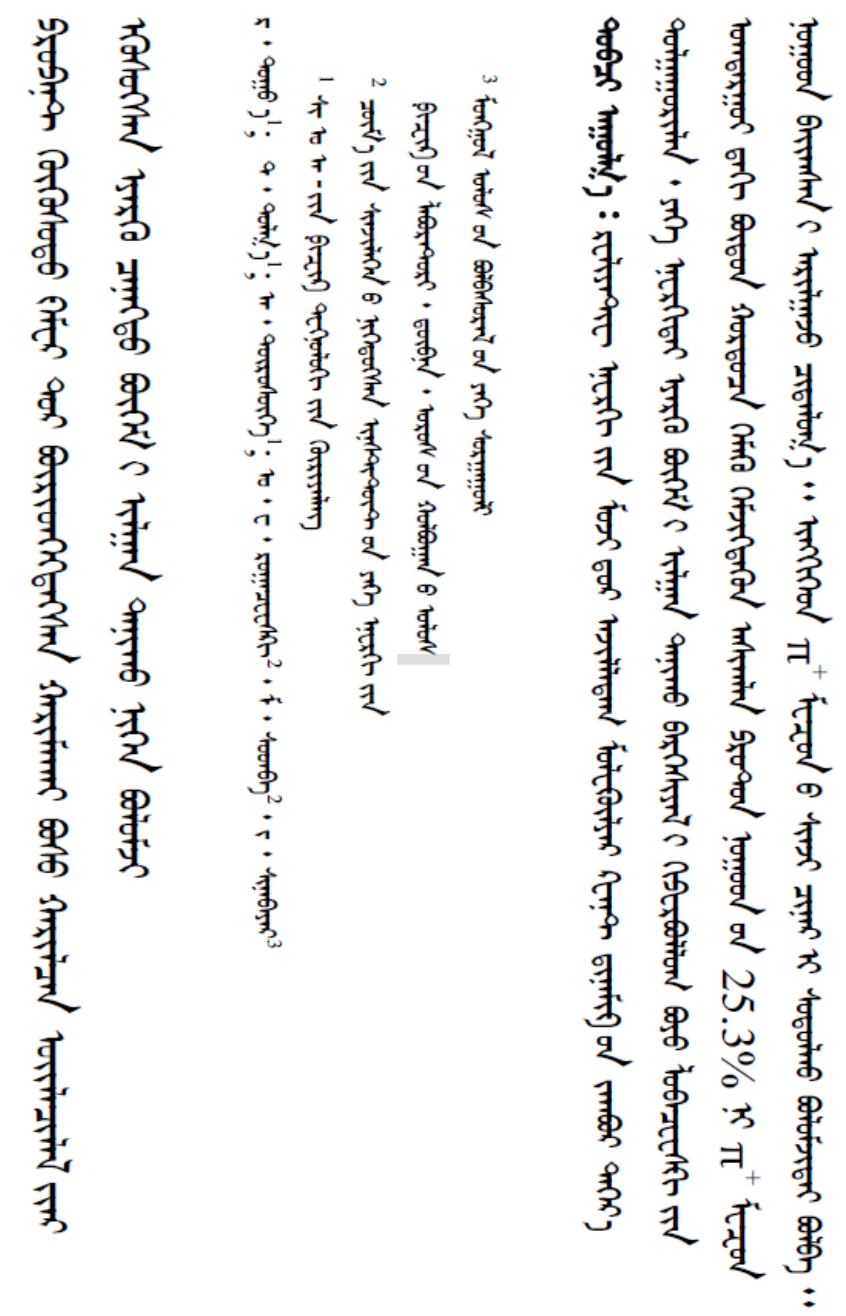